\title{
Hubungan Fungsi Tiroid dengan Energy Expenditure pada Remaja
}

\author{
Maria Mexitalia, ${ }^{*}$ Isfandiyar Fahmi, ${ }^{*}$ Rudy-susanto, ${ }^{*}$ Taro Yamauchi ${ }^{* *}$ \\ *Bagian Ilmu Kesehatan Anak Fakultas Kedokteran Universitas Diponegoro Semarang / RS Dr. Kariadi \\ Semarang Indonesia \\ **Laboratorium of Human Ecology, Graduate School of Health Sciences, Hokkaido University, Sapporo, \\ Japan
}

Latar belakang. Hormon tiroid adalah hormon yang dihasilkan oleh kelenjar tiroid yang berfungsi untuk mensintesis hormon tiroksin (T4) dan 3,5,3 triodotironine (T3). Tiroid diatur oleh thyroid stimulating hormone (TSH), glikoprotein yang diproduksi dan disekresi kelenjar hipofisis anterior. Dilaporkan bahwa hormon TSH meningkat pada obesitas, sedangkan FT3 dan FT4 masih menjadi perdebatan.

Tujuan. Mengetahui hubungan fungsi tiroid dengan energy expenditure pada remaja obesitas dan normal. Metode. Penelitian dilakukan pada anak SMP usia 12-13 tahun di Semarang pada tahun 2008 dengan metode potong lintang. Semua subyek diperiksa komposisi tubuh (indeks masa tubuh / IMT dan persentase lemak tubuh) dengan menggunakan Tanita BC 545, total energy expenditure (TEE) dengan akselerometer dan resting energy expenditure (REE) dihitung berdasarkan rumus WHO. Data dianalisis menggunakan tes t tidak berpasangan dan uji korelasi Spearman.

Hasil. Subyek penelitian 75 remaja (37 obesitas dan 38 normal), dengan rerata umur 13,2 tahun. FT4 dan TSHs remaja laki-laki obesitas lebih tinggi dibanding subyek normal. Terdapat korelasi negatif $(r=-0,29)$ antara FT3 dengan persentase lemak tubuh, korelasi positif antara TSHs dengan IMT $(r=0,30)$ dan persentase lemak tubuh $(r=0,34)$. Tidak didapatkan korelasi antara hormon tiroid dengan REE, tetapi FT3 berkorelasi negatif dengan TEE ( $r=-0,29)$, dan TSHs berkorelasi positif dengan TEE $(r=0,25)$.

Kesimpulan. Didapatkan korelasi positif antara TSHs dengan komposisi tubuh dan TSHs dengan TEE. Kadar TSHs pada laki-laki obesitas lebih tinggi dibanding normal walaupun hasilnya tidak signifikan secara statistik. Sari Pediatri 2011;12(5):323-7.

Kata kunci: Fungsi tiroid, FT4, FT3, TSHs, IMT, TEE, remaja, obesitas

\section{Alamat korespondensi:}

DR. Dr. Maria Mexitalia, Sp.A(K). Bagian IKA FK UNDIP/RS Dr. Kariadi, Jl. Dr. Sutomo 16-18 Semarang Telp./Fax.: 024-8414296 HP: 081325641 808, E-mail :dr.mexitalia@yahoo.com
$\mathrm{M}$ etabolisme energi di dalam tubuh manusia diatur oleh berbagai faktor, salah satunya hormon tiroid. Hormon tiroid adalah hormon yang dihasilkan oleh kelenjar tiroid yang berfungsi untuk mensintesis hormon tiroksin (T4) dan 3,5,3 triodothironine (T3). Kelenjar tiroid berfungsi sebagai regulator 
utama keseimbangan energi dan mempengaruhi perkembangan otak yang diatur oleh tiroidstimulating hormon (TSH), yaitu suatu glikoprotein yang diproduksi dan disekresi oleh kelenjar hipofisis anterior. ${ }^{1,2,3}$

Hormon tiroid mempengaruhi keseimbangan energi melalui beberapa mekanisme. Hormon tiroid merangsang tingkat metabolisme dengan mempercepat jalur sintetik anabolisme dan katabolisme, yang meningkatkan proses pengambilan energi. Hormon tiroid juga berperan penting untuk termogenesis fakultatif dan meningkatkan asupan makanan. ${ }^{4,5}$ Penelitian lain menduga peran hormon tiroid dalam mengatur termogenesis saat udara dingin dan diinduksi oleh diet yang disesuai dengan suhu selama beraktifitas. ${ }^{6,7,8}$ Poros hipotalamik pituitari tiroid (HPT) mengatur energy expenditure, termogenesis, konsumsi oksigen, dan metabolisme makanan. Kerusakan poros hipotalamus paratiroid dan tiroid (HPT) berdampak pada metabolisme, termogenesis, dan berat badan. Rerata produksi dan peningkatan metabolisme kortisol telah dilaporkan pada keadaan obesitas, tetapi kadar dalam serum umumnya normal. ${ }^{9,10}$

Obesitas sering diikuti oleh perubahan hormonal. Poros hipotalamus hipofisis-adrenal bekerja secara hiperaktif pada obesitas. ${ }^{11}$ Dilaporkan bahwa peningkatan kadar serum T3 disebabkan oleh overfeeding. Kadar TSH meningkat, sebaliknya kadar free triiodotironin (FT3) dan free tiroksin (FT4) menurun pada wanita dengan obesitas. Demikian pula pada anak obesitas umur 4 sampai 16 tahun memperlihatkan kadar serum TSH yang lebih tinggi dibandingkan anak-anak tidak obesitas. ${ }^{11,12}$ Penelitian lain menemukan kadar serum TSH meningkat sedikit, sedang kadar FT3 menurun pada wanita obesitas premenopause yang dilakukan intervensi diet penurunan berat badan. Hasil yang berlawanan telah dilaporkan mengenai mekanisme perubahan aktifitas poros HPT untuk merespon penurunan berat badan pada obesitas. ${ }^{13,14,15}$ Sampai saat ini penilaian fungsi tiroid pada keadaan obesitas masih menjadi perdebatan para peneliti.

Total energy expenditure (TEE) terdiri dari resting energy expenditure pada saat aktivitas dan saat istirahat. Penelitian Mexitalia ${ }^{16}$ menyimpulkan bahwa resting energy expenditure (REE) dan TEE pada obesitas lebih rendah dibanding dengan normal setelah dikontrol dengan berat badan. Penelitian pada suku Pima Indians di Meksiko dan di Amerika Serikat bahwa energy expenditure relatif rata rata selama 24 jam dapat menaikkan berat badan. ${ }^{17}$ Sebaliknya, penelitian lain menyimpulkan bahwa tidak ada perbedaan dalam resting metabolic rate (RMR), total energy expenditure (TEE), atau activity energy expenditure (AEE) antara anak remaja obesitas dan normal. ${ }^{3,4}$ Kontroversi ini dijelaskan karena penggunaan definisi yang berbeda dari aktivitas fisik, intensitas dari aktivitas fisik, TEE, dan AEE, dan ketelitian alat penilaian aktivitas fisik yang digunakan. Tidak ada metode tunggal yang dapat mengukur cakupan yang penuh tentang aspek dari aktivitas fisik kehidupan sehari. Oleh karena itu, untuk menguraikan pengaruh dari aspek yang berbeda dari aktivitas fisik terhadap berat badan, kombinasi dari metode obyektif yang berbeda tentang penilaian masih diperlukan. ${ }^{13,16}$

Penelitian fungsi tiroid dengan energy expenditure pada remaja obesitas masih diperlukan mengingat data yang sangat terbatas. Fungsi tiroid pada variabel penelilitian kami mengggunakan free $\mathrm{T} 4$, free $\mathrm{T} 3$, dan TSHs.

\section{Metode}

Desain penelitian potong lintang dengan subyek murid SMP di Semarang, berumur 10-14 tahun, baik menderita obesitas maupun mempunyai gizi normal. Penelitian dilakukan pada bulan Agustus September 2007. Obesitas ditetapkan berdasarkan grafik indeks masa tubuh (IMT) CDC 2000 $>$ persentil ke-95, sedangkan status gizi normal $>$ persentil ke-5 dan <persentil ke-85. Informed consent dimintakan kepada orang tua. Setelah dilakukan pengukuran berat badan dan tinggi badan pada semua murid di sekolah menengah, dipilih subyek penelitian dengan obesitas dan gizi normal secara simple random sampling.

Pemeriksaan komposisi tubuh (berat badan, persentase lemak tubuh) dilakukan dengan Tanita BC 545. Total energy expenditure (TEE) diperiksa dengan accelerometer Kenz Lifecoder ${ }^{\circledR}$ diikatkan dipinggang selama 7 hari. Alat tersebut juga berfungsi untuk mengukur aktivitas fisik. Resting energy expenditure (REE) dihitung berdasarkan tabel WHO. Pemeriksaan fungsi tiroid meliputi TSH sensitif (TSHs), Free T3 (FT3) dan Free T4 (FT4) yang diperiksa secara Eliza di Laboratorium GAKY Fakultas Kedokteran Universitas Diponegoro. Anamnesis dan pemeriksaan 
fisik untuk menyingkirkan keadaan hipotiroid, hipertiroid secara klinik. Analisis data meliputi analisis deskriptif dan uji hipotesis. Data nominal dan ordinal dinyatakan dalam distribusi frekuensi dan data yang bersifat rasio disajikan sebagai rerata dan simpang baku. Dinilai normalitas data dan dilakukan transformasi. Uji hipotesis untuk variabel bebas nominal dikotom dan variabel tergantung numerik dengan uji-t untuk kelompok independen atau Mann Whitney sebagai uji non parametriknya. Uji hipotesis dengan data bersifat numerik dilakukan dengan uji korelasi. Nilai korelasi dianggap baik jika $r>0,8$ sedang 0,6-0,79; lemah 0,4-0,59, dan sangat lemah $<0,4$. Analisis multivariat dilakukan untuk melihat pengaruh fungsi tiroid terhadap energy expenditure pada obesitas dan normal dengan memperhitungkan indeks masa tubuh, umur dan jenis kelamin. Penelitian telah mendapat persetujuan Komisi Etik Penelitian Kesehatan Fakultas Kedokteran Universitas Diponegoro Semarang.

\section{Hasil}

Penelitian diikuti oleh 74 remaja dengan rerata umur 13,2 tahun. Sebagian besar subyek adalah laki-laki (51 orang). Subyek dengan obesitas 37 dan gizi normal 38 anak. Karakteristik subyek dan pemeriksaan antropometri tertera pada Tabel 1 .

Didapatkan IMT dan persentase lemak tubuh pada subyek obesitas secara signifikan lebih tinggi dibandingkan subyek dengan gizi normal. Berdasarkan pemeriksaan fisik tidak didapatkan subyek dengan hipotiroid maupun hipertiroid, dan dari anamnesis didapatkan bahwa semua subyek perempuan telah mengalami menstruasi. Tabel 2 memperlihatkan hasil pemeriksaan hormon tiroid dan energy expenditure.

Tidak didapatkan perbedaan kadar hormon tiroid pada subyek obesitas dengan gizi normal. Energy expenditure pada subyek obesitas lebih tinggi dibandingkan subyek dengan status gizi normal. Namun apabila berat badan diperhitungkan, tampak

Tabel 1. Hubungan antara karakteristik subyek penelitian dengan pemeriksaan antropometri

\begin{tabular}{|c|c|c|c|c|c|c|}
\hline \multirow[t]{2}{*}{ Variabel } & \multicolumn{3}{|c|}{ Laki - laki } & \multicolumn{3}{|c|}{ Perempuan } \\
\hline & $\begin{array}{c}\text { Obesitas } \\
(\text { rerata } \pm S B)\end{array}$ & $\begin{array}{c}\text { Normal } \\
(\text { rerata } \pm S B)\end{array}$ & $\mathrm{p}$ & $\begin{array}{c}\text { Obesitas } \\
(\text { rerata } \pm \text { SB })\end{array}$ & $\begin{array}{c}\text { Normal } \\
(\operatorname{rerata} \pm S B)\end{array}$ & $\mathrm{p}$ \\
\hline $\mathrm{N}$ & 25 & 27 & & 12 & 11 & \\
\hline Ras: Pribumi (n) & 10 & 10 & & 10 & 7 & \\
\hline Cina $(\mathrm{n})$ & 15 & 17 & & 2 & 4 & \\
\hline Umur (tahun) & $13,2 \pm 0,34$ & $13,2 \pm 0,33$ & $0,858^{\mathrm{a}}$ & $13,3 \pm 0,4^{*}$ & $13,24 \pm 0,25$ & 0,487 \\
\hline Berat badan $(\mathrm{kg})$ & $74,1 \pm 11,2$ & $44,8 \pm 5,9$ & $0,313^{a}$ & $70,2 \pm 6,5^{*}$ & $45 \pm 3,54$ & $<0,001$ \\
\hline Tinggi badan $(\mathrm{cm})$ & $159,1 \pm 7,1$ & $157,1 \pm 8,18$ & $<0,001^{a}$ & $155,6 \pm 4,9^{*}$ & $153,7 \pm 4,3$ & 0,347 \\
\hline IMT $\left(\mathrm{kg} / \mathrm{m}^{2}\right)$ & $29,2 \pm 2,97$ & $18,1 \pm 1,2^{*}$ & $<0,001^{a}$ & $29 \pm 2,14$ & $19,0 \pm 0,63$ & $<0,001$ \\
\hline Persentase lemak tubuh (\%) & $31,1 \pm 4,1$ & $15,7 \pm 2,9^{*}$ & $<0,001^{a}$ & $37,0 \pm 3,7$ & $25,7 \pm 1,14$ & $<0,001$ \\
\hline
\end{tabular}

${ }^{a}$ uji Mann-Whitney ${ }^{*}$ signifikan $<0,005$

Tabel 2. Distribusi hormon tiroid dengan energy expenditure menurut jenis kelamin

\begin{tabular}{lcccccc}
\hline Pemeriksaan & \multicolumn{3}{c}{ Laki - laki } & \multicolumn{3}{c}{ Perempuan } \\
\cline { 2 - 6 } & Obesitas & Normal & p & Obesitas & Normal & $(11)$ \\
\hline FT3 (pg/dL) & $2,4 \pm 0,65$ & $2,8 \pm 1,1^{*}$ & $0,366^{a}$ & $1,97 \pm 0,55$ & $2,24 \pm 0,72$ & 0,695 \\
FT4 (ng/dl) & $1,1 \pm 0,3$ & $0,9 \pm 0,29$ & $0,351^{\text {a }}$ & $0,83 \pm 0,3^{*}$ & $1,06 \pm 0,37$ & 0,118 \\
TSHs (mU/L) & $4,0 \pm 2,25$ & $3,1 \pm 1,8^{*}$ & $0,113^{\text {a }}$ & $4,27 \pm 1,27$ & $4,2 \pm 1,97$ & 0,928 \\
REE (kkal/hari) & $2296 \pm 234,7$ & $1651 \pm 121,8$ & $<0,001^{\text {a* }}$ & $1852 \pm 131,8$ & $1525 \pm 56,2$ & $<0,001^{\text {a }}$ \\
TEE (kkal/hari) & $2684 \pm 329,4$ & $2033 \pm 223,5$ & $<0,001^{\text {a* }}$ & $2435 \pm 136,5$ & $1971 \pm 130,5$ & $<0,001^{*}$ \\
TEE/berat badan & $35,5 \pm 5,2$ & $45,6 \pm 3,6$ & $0,002^{\text {a* }}$ & $34,8 \pm 2,8$ & $44,2 \pm 4,3$ & $0,001^{*}$ \\
(kkal/kg/hari) & & & & & \\
\hline
\end{tabular}

a uji Mann-Whitney * signifikan $<0,005$ 
bahwa TEE/ berat badan pada subyek obesitas lebih rendah dibandingkan normal. Jadi subyek obesitas lebih sedikit mengeluarkan energi per-kilogram berat badannya dibandingkan subyek normal.

Tabel 3 memperlihatkan hubungan antara kadar hormon tiroid dengan IMT dan persentase lemak tubuh. Tampak bahwa TSHs berhubungan secara signifikan dengan IMT dan persentase lemak tubuh, sedangkan FT3 berhubungan negatif dengan persentase lemak tubuh. Tabel 4 memperlihatkan hubungan kadar hormon tiroid dengan REE dan TEE. TSHs berhubungan positif dengan TEE, sedangkan FT3 berhubungan negatif dengan TEE. Semakin rendah FT3 maka TEE semakin tinggi. Namun hubungan semua parameter lemah $(r<0,4)$. dilakukan intervensi dengan restriksi kalori, didapatkan penurunan FT3, tetapi tidak didapatkan perubahan FT4. ${ }^{13} \mathrm{Hal}$ ini berbeda dengan penelitian Reihner ${ }^{19}$ pada 55 anak obesitas usia 4,5-16 tahun yang dilakukan program penurunan berat badan (Obeldicks programme) didapatkan penurunan secara signifikan kadar T3 dan T4, tetapi kadar TSH tetap tinggi.

Ortega $^{20}$ yang meneliti pada suku Pima Indian mendapatkan hanya TSH yang berhubungan positif dengan persentase lemak tubuh, sedangkan kadar T3 bebas dan T4 bebas tidak berhubungan dengan persentase lemak tubuh. Penelitian kami mendapatkan bahwa FT3 berhubungan negatif dengan persentase lemak tubuh, sedangkan TSHs berhubungan positif dengan persentase lemak tubuh.

Tabel 3. Uji korelasi kadar hormon tiroid dengan IMT dan persentase lemak tubuh

\begin{tabular}{lcccc}
\hline Variabel & \multicolumn{2}{c}{ IMT } & \multicolumn{2}{c}{ \% lemak tubuh } \\
\cline { 2 - 5 } & $\mathrm{r}$ & $\mathrm{p}$ & $\mathrm{r}$ & $\mathrm{p}$ \\
\hline FT3 $(\mathrm{pg} / \mathrm{dL})$ & $-0,18$ & 0,132 & $-0,29$ & $0,011^{*}$ \\
FT4 $(\mathrm{ng} / \mathrm{dl})$ & $-0,004$ & 0,970 & $-0,003$ & 0,980 \\
TSHs $(\mathrm{mU} / \mathrm{L})$ & 0,30 & $0,011^{*}$ & 0,34 & $0,003^{*}$ \\
\hline
\end{tabular}

Tabel 4. Uji korelasi kadar hormon tiroid dengan REE dan TEE

\begin{tabular}{lcccc}
\hline Variabel & \multicolumn{2}{c}{ REE } & \multicolumn{2}{c}{ TEE } \\
\cline { 2 - 5 } & $\mathrm{r}$ & $\mathrm{p}$ & $\mathrm{r}$ & $\mathrm{p}$ \\
\hline FT3 $(\mathrm{pg} / \mathrm{dL})$ & 0,03 & 0,819 & $-0,28$ & $0,016^{*}$ \\
FT4 $(\mathrm{ng} / \mathrm{dl})$ & 0,08 & 0,507 & 0,19 & 0,114 \\
TSHs (mU/L) & 0,18 & 0,133 & 0,25 & $0,021^{*}$ \\
\hline
\end{tabular}

\section{Pembahasan}

Salah satu perubahan hormonal pada obesitas adalah pada hormon tiroid. Dikatakan poros hipotalamushipofisis-adrenal bekerja secara hiperaktif pada obesitas. ${ }^{11}$ Sebaliknya perubahan hormon tiroid terutama peningkatan TSH dan penurunan T3 dan T4 akan mempengaruhi energy expenditure yang akhirnya akan mempengaruhi terjadinya obesitas. Pada subyek penelitian kami didapatkan kadar FT3 pada subyek obesitas laki-laki lebih rendah dibanding dengan subyek normal. Namun pada uji korelasi tidak didapatkan hubungan antara FT3 dengan indeks massa tubuh (IMT). Hal ini sesuai dengan penelitian Knudsen ${ }^{18}$ yang mendapatkan hanya TSH yang berhubungan secara negatif dengan IMT, tetapi tidak ada hubungan antara FT3 dan FT4 dengan IMT. Demikian pula penelitian di Belanda pada wanita obesitas dewasa yang
Sebagian besar penelitian pada obesitas dengan hipotiroid subklinik mendapatkan kadar TSH rendah, FT3 bisa rendah atau normal, sedangkan FT4 normal. ${ }^{12,13,21}$ Pada keadaan obesitas didapatkan resetting thyrostat sentral menjadi lebih tinggi dibanding keadaan normal. Hal ini bisa mengakibatkan kadar TSH, FT3 dan FT4 meningkat, tetapi dengan adanya resetting thyrostat tersebut bisa mengakibatkan penurunan FT3 intraselular. ${ }^{11}$

Pengeluaran energi saat istirahat (REE) menurun 15\% ketika TSH meningkat antara 0,1 dan $10 \mathrm{mU} / \mathrm{L}$. Dengan kata lain $R E E$ berhubungan negatif dengan TSH. ${ }^{5}$ Pada penelitian kami tidak didapatkan korelasi antara REE dengan TSH, tetapi didapatkan korelasi positif antara TEE dengan TSH dan korelasi negatif antara TEE dengan FT3. Tagliaferri ${ }^{21}$ yang meneliti pada subyek dengan obesitas dan hipotiroid subklinik (kadar TSH >2 SD) dibandingkan dengan obesitas 
dengan fungsi tiroid normal, menyimpulkan bahwa energy expenditure akan dipengaruhi oleh hormon tiroid hanya bila TSH di atas normal.

Tampak beberapa penelitian menunjukkan hasil yang berbeda, tetapi pada anak dengan obesitas yang seringkali disertai dengan hipotiroid subklinik, pemeriksaan hormon tiroid khususnya TSHs merupakan hal yang cukup penting dilakukan, mengingat pada penelitian kami dan sebagian besar penelitian lainnya mendapatkan hubungan positif antara TSH dengan IMT maupun persentase lemak tubuh.

\section{Daftar pustaka}

1. Butte NF. Fat intake of children in relation to energy requirements. Am J Clin Nutr 2000;72:1246-52.

2. Brook CG, Clayton PE, Brown RS, Huang $S$. The thyroid and its disorder in clinical pediatric endocrinology. Blackwell 2006;218-38.

3. Mehmet B, Fulya A, Esma A, Buyamin K. Obesity is associated with increased serum TSH level, independent of thyroid function. Swiss Med Wkly 2007;137:431-4.

4. Stubbs CO, Lee AJ. The obesity epidemic: both energy intake and physical activity contribute. Medical Journal of Australia 2004;181:489-91.

5. Al-Adsani H, Hoffer LJ And Silva JE. Resting Energy expenditure is sensitive to small dose changes in patients on chronic thyroid hormon replacement. J Clin Endocrinol Metab 2006;82:1118-25.

6. Silva JE. Thermogenic Mechanisms and their hormonal regulation. Physiol Rev 2006;86:435-64.

7. Bianco AC, Maia AL, da Silva WS, Christoffolete MA. Adaptive activation of thyroid hormone and energy expenditure. Biosci 2005;25:191-08.

8. Lowell BB. Regulation of energy expenditure. Chapter 4. Dalam: tschoep M, penyunting: Endotext.com. Endotext 2002;4:120-6.

9. Katzeff HL, Selgrad C. Maintenance of thyroid hormone production during exercise-induced weight loss. Am Physiol Soc 1991;91:193-849.

10. DeLany JP, Bray GA, Harsha DW, Volaufova J. Energy expenditure in preadolescent African American and white boys and girls: the Baton Rouge children's study. Am J Clin Nutr 2002;75:705-13.
11. Michalaki MA, Vagenakis AG, Leonardou AS, Argentou MN, Habeos IG, Makri MG, dkk. Thyroid function in humans with morbid obesity. Mary Ann Liebert 2006;16:73-8.

12. Papi G, Uberti AD, Betterle C, Carani C, Pearce EN, Braverman LE, dkk. Subclinical hypothyroidism. Lippincott Williams \& Wilkins 2007;14:197-208.

13. Kok P, Roelfsema F, Langendonk JG, Frölich M, Burggraaf J, Meinders AE, dkk. High circulating thyrotropin levels in obese women are reduced after body weight loss induced by caloric restriction. J Clin Endocrinol Metab 2005;90:4659-63.

14. Miyakawa M, Murakami TTH, Isozaki O And Takano K. Serum leptin levels and of body composition in and hypothyroidism. Endocrine Journal 1999;46:665-73.

15. Rosenbaum M, Hirsch J, Murphy E, Leibel RL. Effects of changes in body weight on carbohydrate metabolism, catecholamine excretion, and thyroid function. Am J Clin Nutr 2000;71:1421-32.

16. Mexitalia SE. Faktor risiko obesitas pada remaja: dikaji dari sudut energy expenditure dan polimorfisme gen uncoupling protein 2 dan 3. [Disertasi Doktor Ilmu Kedokteran] Semarang: Universitas Diponegoro; 2010.

17. Esparza J, Fox C, Harper IT, Bennett PH, Schulz LO, Valencia ME and Ravussin E. Daily energy expenditure in Mexican and USA Pima Indians: low physical activity as a possible cause of obesity. Int J Obes 2000;24:55-9.

18. Knudsen N, Laurberg P, Rasmussen LB, Bulow I, Perrild $\mathrm{H}$, Ovesen L, and Jorgensen T. Small differences in thyroid function may be important for body mass index and the occurrence of obesity in the population. J Clin Endocrinol Metab 2005;90:4019-24.

19. Reinehr T, Andler W. Thyroid hormone before and after weight loss in obesity. Arch Dis Child 2002;87:320-3.

20. Ortega E, Pannacciulli N, Bogardus, Krakoff. Plasma concentrations of free triiodotyronine predict weight change in euthyroid persons. Am J Clin Nutr 2007;85:440-5.

21. Tagliaferri M, Berselli ME, Calo G, Minocci A, Giulio S, Petroni ML, Viberti GC, Liuzzi A. Subclinical hypotiroidism in obese patients: relation to resting energy expenditure, serum leptin, body composition and lipid profile. Obesity Research 2001;9:196-200. 